\title{
Short-Term Fluctuations of Sugar Beet Damping-Off by Pythium ultimum in Relation to Changes in Bacterial Communities After Organic Amendments to Two Soils
}

\author{
Miaomiao He, Guangming Tian, Alexander M. Semenov, and Ariena H. C. van Bruggen
}

First and second authors: Department of Life and Environmental Science, Hangzhou Normal University, Hangzhou 310036, China, and Department of Environment and Resource, Zhejiang University, Hangzhou 310029, China; third author: Department of Microbiology, Biological Faculty, Moscow State University, 119899 Vorob’evy Gory, Moscow, Russia; and fourth author: Biological Farming Systems, Wageningen University, P.O. Box 563, 6700 AN Wageningen, The Netherlands.

Current address of A. H. C. van Bruggen: Emerging Pathogens Institute and Department of Plant Pathology, University of Florida, P.O. Box 110680, Gainesville 32611-0680.

Accepted for publication 25 November 2011.

\begin{abstract}
He, M., Tian, G., Semenov, A. M., and van Bruggen, A. H. C. 2012. Short-term fluctuations of sugar beet damping-off by Pythium ultimum in relation to changes in bacterial communities after organic amendments to two soils. Phytopathology 102:413-420.

Previously, oscillations in beet seedling damping-off by Pythium ultimum, measured as area under the disease progress curve (AUDPC), were demonstrated after incorporation of organic materials into organic and conventional soils. These periodic fluctuations of $P$. ultimum infections were cross-correlated with oscillations of copiotrophic CFU at lags of 2 to 4 days. For this article, we investigated whether bacterial communities and microbial activities fluctuated after a disturbance from incorporation of organic materials, and whether these fluctuations were linked to the short-term oscillations in AUDPC of beet seedling dampingoff and bacterial populations (CFU) in soil. Soil microbial communities studied by polymerase chain reaction-DGGE analysis of $16 \mathrm{~S}$ DNA after isolation of total DNA from soil and microbial activities measured as $\mathrm{CO}_{2}$ emission rates were monitored daily for 14 days after addition of grassclover (GC) or composted manure (CM) into organic versus conventional soils. Similar to our previous findings, AUDPC and density of copiotrophic bacteria oscillated with time. Fluctuations in species richness (S), Shannon diversity index $(\mathrm{H})$, and individual amplicons on DGGE gels

were also detected. Oscillations in AUDPC were positively crosscorrelated with copiotrophic CFU in all soils. Oscillations in AUDPC were also positively cross-correlated with 19 to $35 \%$ of the high-intensity DNA fragments in soils amended with GC but only 2 to $3 \%$ of these fragments in CM-amended soils. AUDPC values were negatively crosscorrelated with 13 to $17 \%$ of the amplicons with low average intensities in CM-amended soils, which were not correlated with densities of copiotrophic CFU. $\mathrm{CO}_{2}$ emission rates had remarkable variations in the initial 7 days after either of the soil amendments but were not associated with daily changes in AUDPC. The results suggest that infection by P. ultimum is hampered by competition from culturable copiotrophic bacteria and some high-intensity DGGE amplicons, because AUDPC is cross-correlated with these variables at lags of 1 to 4 days. However, negative crosscorrelations with low-intensity DNA fragments indicate that $P$. ultimum infection could also be suppressed by antagonistic bacteria with low densities that may be nonculturable species, especially in CM amended soil. The organic soil generally had lower AUDPC values, higher bacterial diversity, and negative cross-correlations between AUDPC and lowintensity DNA fragments (after CM amendment), indicating that specific bacteria that do not attain high densities may contribute to $P$. ultimum suppression in organic soils.
\end{abstract}

Based on the temporal data of area under the disease progress curve (AUDPC) for seedling damping-off (by Pythium ultimum) after a nutrient impulse into soils, a new phenomenon was proposed: damping-off did not simply increase immediately after incorporation of organic materials into soils and decrease thereafter as formerly reported $(9,23)$ but increased and decreased in a wavelike pattern with regular intervals (18). Experiments with soils which were amended with organic materials and inoculated with $0.1 \%$ (vol/vol) P. ultimum showed that AUDPC of sugar beet damping-off fluctuated with significant harmonics over time (18). Moreover, harmonics analysis demonstrated that AUDPC in the organically managed soil always had smaller amplitudes and lower frequencies than that in the conventionally managed soil after amendments, suggesting that the organic soil was healthier $(38,39)$.

Corresponding author: A. H. C. van Bruggen;

E-mail address: ahcvanbruggen@ufl.edu

http://dx.doi.org/10.1094/PHYTO-07-11-0189

(c) 2012 The American Phytopathological Society
The fluctuations in seedling damping-off could be the consequence of microbial growth and death cycles in soils after a disturbance. Wavelike patterns in microbial populations had been observed many times $(38,46)$. The impulse of nutrients would lead to immediate growth of microorganisms followed by death due to local nutrient limitation and, subsequently, by growth again from reuse of carbon sources supplied from decaying soil organic matter and dead cells. Given that the responses of pathogens to a nutrient pulse are similar to those of microorganisms, plant infections might also fluctuate in wavelike patterns, and even show fluctuation characteristics similar to those of microbial populations. Some species of plant pathogens have nutrient requirements similar to those of bacteria $(12,25)$ and, indeed, AUDPC harmonics for $P$. ultimum displayed periods similar to those of $\mathrm{CFU}$ of copiotrophic bacteria after incorporation of organic materials into soils (18). Analogously, the periods of the wave-like distribution of Pythium spp. infections were similar to those of copiotrophic bacteria along wheat roots (40). However, the phase had shifted between the oscillations in pathogen infections and copiotrophic CFU in both the temporal and spatial dimensions $(18,40)$. 
Microbial activity and biodiversity in soil are important factors influencing plant disease suppression $(1,6,30)$. Therefore, another potential explanation for the wavelike patterns in AUDPC could be the fluctuation in bacterial metabolic activity and succession of competitive or antagonistic bacteria species within microbial communities. Infection could possibly take place more easily when microbial abundance and activity decline $(7,30)$ but fluctuations in microbial activity in disturbed soil have not been widely published $(4,7)$. The diversity of bacterial amplicons obtained by DGGE oscillated over time and along roots $(10,41)$. The bacterial communities were similar when CFU increased or decreased in successive waves, indicating that succession took place within one waxing and waning phase of each wave rather than between waves. The succession of competitors and antagonists might result in alternating levels of competition between particular bacteria and plant pathogens, so that oscillations in disease incidence could be observed.

Various studies have been carried out on changes in soil microbial activities and community structures after implementation of agricultural practices $(8,13,26,29,37,45)$, and several investigations have focused on the suppressive effects of soil bacterial biomass, activity, and diversity on pathogen infections $(15,16,21,30,31,36)$. In all of these studies, microbial communities were investigated for specific groups (13), sampling times were sparse and intervals were long $(8,26)$, or only a general description of suppressive effects of soil microbial functions was given (31). No detailed research on correlations between daily changes in plant pathogen infections and short-term variations of genetic composition of soil microbial communities or microbial activity after a disturbance has been conducted to date.

The overall goal of this research was to characterize the shorttime oscillations of infections by the root pathogen P. ultimum in relation to bacterial communities and microbial activity after addition of organic materials to organic and conventional soils under controlled environmental conditions. Specific objectives were to investigate whether (i) short-term fluctuations in pathogen infections are correlated with changes in bacterial communities or activities and (ii) how soil bacterial communities and microbial activities fluctuate in a time series after input of organic nutrients. The experiments were carried out with two kinds of organic amendments in organic and conventional soils, which allowed us to address the additional aim of whether (iii) fluctuations in microbial activity, diversity, and plant infections differed in soils with different management strategies.

\section{MATERIALS AND METHODS}

Experimental setup. Two experiments were carried out in spring and summer 2007, respectively. Two series of PVC pots (diameter $=10.2 \mathrm{~cm}$ and depth $=25 \mathrm{~cm})$ containing soil without amendments (control series) or soil amended with a mixture of grass and clover (GC treatment, spring experiment) or composted cattle manure (CM treatment, summer experiment) were used. The collection, addition rates, and properties of the two amendments were reported previously (18).

There were three pots for each sampling time and treatment in each experiment. The pots were randomized in blocks in a controlled environment room at $20^{\circ} \mathrm{C}$. The day before the start of each experiment, moisture of the two soils was adjusted to $14.6 \%$ and both amendments were added as dry and milled materials. At the start of each experiment (day 0), inoculum of $P$. ultimum was mixed into all soils at a rate of $0.1 \%(\mathrm{vol} / \mathrm{vol})$ to overwhelm the low level of $P$. ultimum naturally occurring in the soils (based on a preliminary experiment with the same soils). Fresh inoculum of $P$. ultimum was prepared in a soil-oatmeal culture (42). The soils with or without amendments were dispensed into PVC pots to a height of $20 \mathrm{~cm}$. To minimize water-vapor losses while allowing air exchange, a thin plastic film was used to cover every pot.
Soils and subsampling. Experiments were carried out with two pairs of sandy soils as previously published (18).

Three pots of each series (one per block) were randomly taken from the incubator every day. The $\mathrm{CO}_{2}$ emission rates were measured first using a closed chamber system (Innova 1412; LumaSense Technologies, Denmark). Then, subsamples were collected separately for $P$. ultimum bioassays, quantification of copiotrophic bacterial populations (CFU), and direct bacterial DNA extraction (two blocks only).

Plate counting of bacteria. Soil (10 g) was added to $90 \mathrm{ml}$ of sterile deionized water and shaken on a rotary shaker for $15 \mathrm{~min}$ at $300 \mathrm{rpm}$. The suspension was sonicated for $5 \mathrm{~min}$ in an ultrasonic bath. Ten-fold serial dilutions were made. For amended soils, $50 \mu \mathrm{l}$ of $10^{-5}$ and $10^{-6}$ suspensions were plated onto triplicate plates with high carbon ( $\mathrm{C}$ at $1,000 \mathrm{ppm}$ ) media for copiotrophic bacteria to determine CFU per gram of dry soil as described previously $(35,41)$. For nonamended soils, $50 \mu \mathrm{l}$ of $10^{-4}$ and $10^{-5}$ suspensions were plated. Bacterial colonies were counted after $48 \mathrm{~h}$ of incubation at $25^{\circ} \mathrm{C}$.

DNA isolation and polymerase chain reaction-DGGE analyses. The soil samples from days 0 to 14 in two blocks were analyzed for DNA composition. The microbial community DNA was extracted directly from soil samples $(\approx 0.4 \mathrm{~g})$. DNA extraction was done using the FastDNA SPIN Kit for soil following the manufacturer's instructions.

The polymerase chain reaction (PCR) amplification was carried out with the bacterial primers U968GC and L1401r (19) and the touchdown scheme (33) for 30 thermal cycles. The region of 450-bp-long products was checked on $1.2 \%$ agarose gels in Trisborate-EDTA buffer and stained with ethidium bromide. Samples were randomized on DGGE gels.

DGGE was performed with the Bio-Rad Dcode system. PCR products (40 $\mu \mathrm{l}$ each) were loaded onto the denaturing gradients. A $6 \%$ polyacrylamide gel (acrylamide/bisacrylamide, 37.5:1) with 45 to $60 \%$ denaturing gradient (28) was used to separate bacterial amplicons. Electrophoresis was performed in Tris-acetate-EDTA buffer for $16 \mathrm{~h}$ at $100 \mathrm{~V}$ at a constant temperature of $60^{\circ} \mathrm{C}$. BioRad's Silver Stain (Bio-Rad Laboratories, Detroit) was used to stain the gels (3) according to the manufacturer's protocol.

Soil $\mathrm{CO}_{2}$ flux measurement. The Closed Chamber Soil Trace Gas Flux Monitor (Innova 1412; LumaSense Technologies) was used to measure $\mathrm{CO}_{2}$ emissions from the different soils. It was programmed to take seven measurements within $6 \mathrm{~min}$. The gas flux $F(t)$ calculation was $F(t)=(V / A) /(d C / d t)$, where $F(t)=$ gas flux (milligrams per square meter per hour), $V=$ chamber headspace volume (cubic meters), $A=$ chamber surface area (square meters), and $d C / d t=$ the slope of the linear regression of seven measurements of headspace gas concentration (milligrams per cubic meter) with measurement intervals of $1 \mathrm{~min}$.

Bioassays with $\boldsymbol{P}$. ultimum. The bioassays with $P$. ultimum were carried out in a separate climate chamber set at $20^{\circ} \mathrm{C}$ with $16 \mathrm{~h}$ of light. Thirty seeds of sugar beet ('Anastasia') were sown in one pot ( 0.6 liter) per soil sample collected daily from the main experiments. On days 14, 18, and 21 after sowing the seed, the numbers of healthy seedlings were scored and the numbers of completely damped-off or dead plants (30 minus the number of healthy seedlings) were calculated. The AUDPC (5) was calculated as described previously (18).

Statistical analysis. Untransformed CFU and AUDPC of damping-off in the soils were compared by one-sided paired $t$ tests between treatments using SPSS 15.0 for Windows. Variances in CFU were small for each time period and were similar enough among treatments to warrant the use of untransformed data.

The scanned images of the DGGE gels were analyzed using Phoretix 1D (NonLinear Dynamics Ltd., Newcastle upon Tyne, $\mathrm{UK}$ ), and the relative densities of amplified fragments were calculated. Bacterial diversity was estimated from DGGE banding patterns in two different ways: species richness and Shannon index. 
Species richness was the number of DGGE fragments detected, disregarding their relative intensities. The Shannon index of bacterial diversity was calculated as $H^{\prime}=-P_{i} \log P_{i}$ based on the relative band intensities (11). $P_{i}$ was the relative intensity of each amplified fragment which was defined as ni/N, where ni is the height of a peak in intensity and $\mathrm{N}$ is the sum of all peak heights in the given DGGE gel profile.

Cross-correlation functions at 0.05 significance levels were calculated for all variables over time with SPSS 15.0 for Windows.

\section{RESULTS}

Pythium spp. infections. AUDPC values for sugar beet damping-off fluctuated in all treatments, with similar fluctuations for each treatment in the three blocks over a period of 14 days. Because the fluctuations were not exactly synchronous and mean values would mask any significant oscillations, the results from single blocks are presented rather than averages of the three blocks, as mentioned in a previous article (18). The AUDPC values in amended conventional soils were significantly higher than in amended organic soil $(P<0.05)$ (Fig. 1). In the spring experiment, the AUDPC values decreased immediately after input of GC into both soils but increased after 1 day, with the first peak on the second and third days in organic and conventional soils, respectively (Fig. 1A). After the first peak, the AUDPC fluctuated at intervals of 4 and 3 days in GC-treated organic and conventional soils, respectively. The AUDPC in organic soils also decreased immediately after addition of $\mathrm{CM}$ and increased after 2 days, with the first remarkable peak on the third day (Fig. 1B). The first peak was followed by continuous oscillations for 14 days. For the CM-amended conventional soil, the AUDPC increased immediately in the initial 2 days, reached the first peak on the
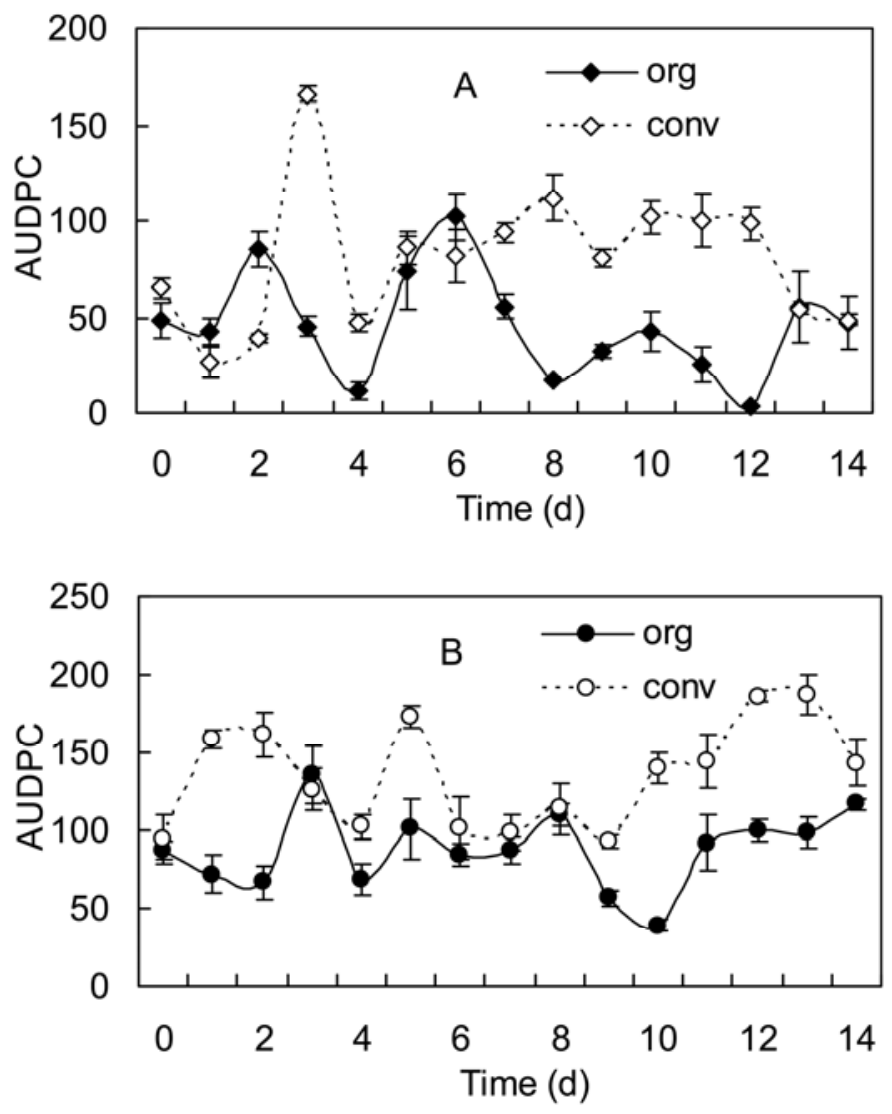

Fig. 1. Fluctuations in area under the disease progress curve (AUDPC) of damping-off of sugar beet seedlings by Pythium ultimum in organic (org) and conventional (conv) soils over time in days since incorporation of $\mathbf{A}$, grassclover or $\mathbf{B}$, composted manure. second day, dropped, and rose again with the second peak after 5 days (Fig. 1B). These initial two peaks were followed by two fluctuations within 14 days. The mean standard errors (three blocks) for AUDPC were 8.45 and 6.93 for GC-amended organic soil and conventional soil, respectively, and 9.72 and 11.69 for CM-amended organic soil and conventional soil, respectively. The mean errors among replications were small compared with the variations over time. The variations of AUDPC in nonamended soils were relatively small. The ranges of AUDPC were 80 to 103 and 70 to 117 in organic and conventional soil, respectively, of the spring experiment and 90 to 122 and 115 to 145 in organic and conventional soil, respectively, of the summer experiment.

Bacterial CFU. Fluctuations were also noticeable in the data of copiotrophic CFU for all three blocks but they were not exactly synchronous and, again, the results of single blocks are presented instead of averages of the three blocks. Addition of organic materials significantly enhanced the numbers of copiotrophic CFU in soils, as shown in another article (18). The average number and fluctuations of $\mathrm{CFU}$ in GC-amended conventional soil were significantly larger than in GC-amended organic soil $(P<$ 0.001) (Fig. 2A). The CFU increased immediately after input of plant residues and reached the first peak after 1 day in both soils. These peaks appeared 1 and 2 days ahead of the first peak of AUDPC in GC-treated organic and conventional soil, respectively. The CFU continued to fluctuate, with two oscillations in both GC-amended soils, which were observed 1 to 2 days earlier than AUDPC peaks. In the summer experiment, the oscillations of $\mathrm{CFU}$ in CM-amended soils were much weaker than in GC-treated soils (Fig. 2B). The first peak of CFU in CM-amended organic and conventional soil occurred after an increase for 4 and 3 days, respectively, which lagged 1 day behind the first peaks in AUDPC. In the following days, the bacterial populations continued to fluctuate, with two peaks within 14 days, and these peaks
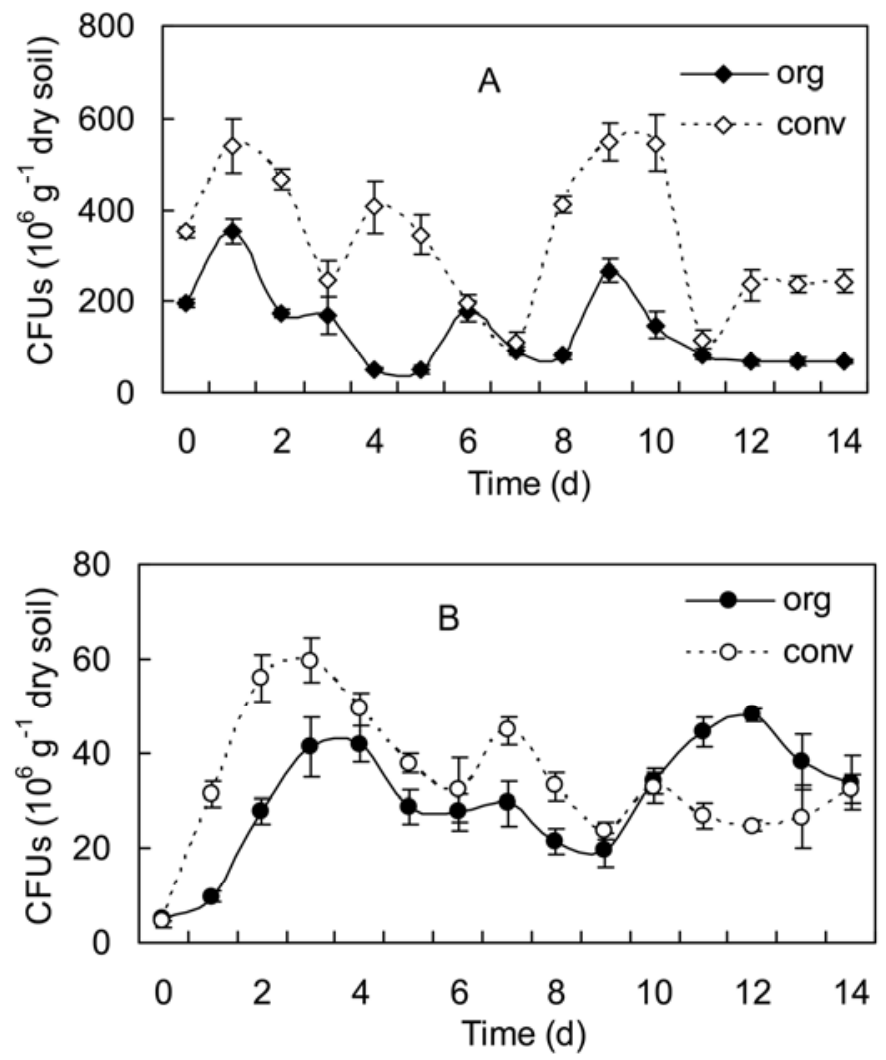

Fig. 2. Fluctuations in copiotrophic CFU in organic (org) and conventional (conv) soils over time after incorporation of $\mathbf{A}$, grass-clover or $\mathbf{B}$, composted manure. 
appeared 2 to 4 days and 2 days behind AUDPC peaks in CMtreated organic and conventional soils, respectively. The mean standard errors for copiotrophic CFU were $15.02 \times 10^{6}$ and $13.30 \times$ $10^{6} \mathrm{~g}^{-1}$ of dry soil for GC-amended organic soil and conventional soil, respectively, and $3.45 \times 10^{6}$ and $3.56 \times 10^{6} \mathrm{~g}^{-1}$ of dry soil for CM-amended organic soil and conventional soil, respectively. Again, the mean errors for replications were negligible compared with the changes over time. In the control series, copiotrophic CFU were much lower than in amended soils, with weaker fluctuations: the ranges of CFU in organic and conventional soils were 7.82 to $19.69 \times 10^{6}$ and 3.61 to $12.20 \times 10^{6} \mathrm{~g}^{-1}$ of dry soil, respectively, in the spring experiment and 5.41 to $9.78 \times 10^{6}$ and 2.19 to $6.01 \times 10^{6} \mathrm{~g}^{-1}$ of dry soil, respectively, in the summer experiment.

There were significant $(P<0.05)$ positive correlations between AUDPC and copiotrophic CFU at a lag of 4 and 2 days in GCamended organic soil and conventional soil, respectively (Table 1). In the summer experiment, the AUDPC data also showed significant $(P<0.05)$ positive correlations with $\mathrm{CFU}$; however, the correlations were observed when AUDPCs were moved backward 2 and 1 days in CM-treated organic and conventional soils, respectively. Indeed, the AUDPC fluctuations were shifted compared with those of copiotrophic CFU, as observed visually.

Soil $\mathrm{CO}_{2}$ emissions. Soil $\mathrm{CO}_{2}$ emission rate could be used as an index to represent soil microbial activity (34). Significant variations in $\mathrm{CO}_{2}$ emissions in both experiments were observed in the initial 7 days after addition of organic materials (Fig. 3). Soil $\mathrm{CO}_{2}$ emission rate increased immediately after $\mathrm{GC}$ incorporation and reached the first peak after 2 days (Fig. 3A) (i.e., 1 day behind the first peak in $\mathrm{CFU}$ ). In the following days, $\mathrm{CO}_{2}$ emission rate in GC-amended organic soil declined and rose appreciably but no significant oscillations appeared until the end of the experiment. $\mathrm{CO}_{2}$ emission rate in $\mathrm{GC}$-amended conventional soil reached the second small peak on the fourth day, then decreased slowly from $\approx 190$ to 130 or $175 \mathrm{mg} \mathrm{m}^{-2} \mathrm{~h}^{-1}$ depending on the origin of the soil. There were significant positive correlations between $\mathrm{CO}_{2}$ emission and $\mathrm{CFU}$ at a lag of 1 day (Table 1). This meant that soil microbial activity for all bacteria took place 1 day later than copiotrophic bacteria reproduction after the addition of GC to soil. In the summer experiment, the $\mathrm{CO}_{2}$ emission rate also went up immediately after input of CM, with the first peak on the first day (Fig. 3B), which was much faster than copiotrophic
CFU. Thus, soil $\mathrm{CO}_{2}$ emission rates were significantly positively correlated with $\mathrm{CFU}$, and changes in $\mathrm{CO}_{2}$ emission took place 1 day earlier than that in copiotrophic CFU (Table 1). After the initial peak, soil $\mathrm{CO}_{2}$ emission declined sharply in the following 5 days and changed with negligible fluctuations to the end of the experiment. Final emission rates were $\approx 17$ to $20 \mathrm{mg} \mathrm{m}^{-2} \mathrm{~h}^{-1}$. There were less significant fluctuations in $\mathrm{CO}_{2}$ emission after the first peak, so that AUDPC fluctuations could not be attributed to soil $\mathrm{CO}_{2}$ release. Indeed, no significant correlations were found
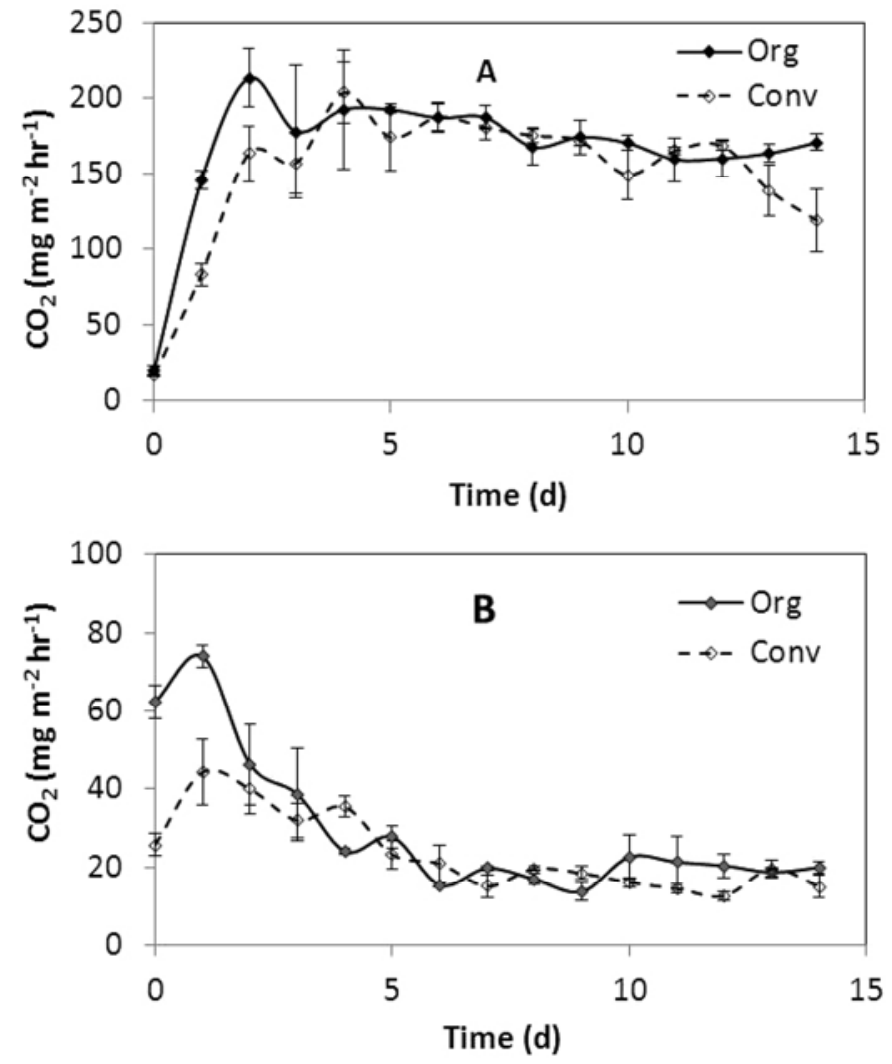

Fig. 3. Daily changes in soil $\mathrm{CO}_{2}$ emission rate in organic (org) and conventional (conv) soils after incorporation of $\mathbf{A}$, grass-clover or $\mathbf{B}$, composted manure.

TABLE 1. Cross-correlations (CC) (significant at $P=0.05$ ) among area under the disease progress curve (AUDPC), $\mathrm{CFU} \mathrm{CO}_{2}$ emission rates, bacterial richness $(\mathrm{S})$, and Shannon diversity index $(\mathrm{H})$ in organic $(\mathrm{Org})$ and conventional (Conv) soils after incorporation of grass-clover $(\mathrm{GC})$ or composted manure $(\mathrm{CM})^{\mathrm{a}}$

\begin{tabular}{|c|c|c|c|c|c|c|c|c|c|c|}
\hline \multirow[b]{2}{*}{ Variable, treatment } & \multicolumn{2}{|c|}{ AUDPC } & \multicolumn{2}{|c|}{$\mathrm{CFU}$} & \multicolumn{2}{|c|}{$\mathrm{CO}_{2}$} & \multicolumn{2}{|c|}{ S } & \multicolumn{2}{|c|}{$\mathrm{H}$} \\
\hline & $\mathrm{CC}$ & Lag (days) & $\mathrm{CC}$ & Lag (days) & $\mathrm{CC}$ & Lag (days) & $\mathrm{CC}$ & Lag (days) & $\mathrm{CC}$ & Lag (days) \\
\hline \multicolumn{11}{|l|}{ CFU } \\
\hline Org-GC & 0.627 & -4 & $\ldots$ & $\ldots$ & $\ldots$ & $\ldots$ & $\ldots$ & $\ldots$ & $\ldots$ & $\ldots$ \\
\hline Org-CM & 0.724 & 2 & $\ldots$ & $\ldots$ & $\ldots$ & $\ldots$ & $\ldots$ & $\ldots$ & $\cdots$ & $\ldots$ \\
\hline Conv-CM & 0.494 & 1 & $\ldots$ & $\ldots$ & $\ldots$ & $\ldots$ & $\ldots$ & $\ldots$ & $\ldots$ & $\ldots$ \\
\hline \multicolumn{11}{|l|}{$\mathrm{CO}_{2}$} \\
\hline Conv-CM & $\mathrm{ns}$ & $\ldots$ & 0.693 & -1 & $\ldots$ & $\ldots$ & $\ldots$ & $\ldots$ & $\ldots$ & $\ldots$ \\
\hline \multicolumn{11}{|l|}{$S$} \\
\hline Org-GC & ns & $\ldots$ & $\mathrm{ns}$ & $\ldots$ & ns & $\ldots$ & $\ldots$ & $\ldots$ & $\ldots$ & $\ldots$ \\
\hline Conv-GC & $\mathrm{ns}$ & $\ldots$ & $\mathrm{ns}$ & $\ldots$ & $\mathrm{ns}$ & $\ldots$ & $\ldots$ & $\ldots$ & $\ldots$ & $\ldots$ \\
\hline Org-CM & ns & $\ldots$ & ns & $\ldots$ & 0.591 & 1 & $\ldots$ & $\ldots$ & $\ldots$ & $\ldots$ \\
\hline Conv-CM & $\mathrm{ns}$ & $\ldots$ & -0.570 & 2 & ns & $\ldots$ & $\ldots$ & $\ldots$ & $\ldots$ & $\ldots$ \\
\hline
\end{tabular}

\footnotetext{
${ }^{a}$ Lag $<0$ means that variable indicated in the leftmost cell (i.e., first variable) leads the variable indicated in the top cell; Lag $>0$ means that variable indicated in
} the far left column follows the variable indicated in the top cell with $|\mathrm{Lag}|$ number of days; ns = not significant. 
between AUDPC and soil $\mathrm{CO}_{2}$ emission rate (Table 1). Nonamended soils had comparatively small changes in $\mathrm{CO}_{2}$ emission rate over time: the ranges of $\mathrm{CO}_{2}$ emission in organic and conventional soils were 12 to 28 and 11 to $59 \mathrm{mg} \mathrm{m}^{-2} \mathrm{~h}^{-1}$, respectively, in the spring experiment and 5 to 14 and 2 to $5 \mathrm{mg} \mathrm{m}^{-2} \mathrm{~h}^{-1}$, respectively, in the summer experiment.

Bacterial community composition. More than 100 fragments could be distinguished on DGGE gels of bacterial DNA from all amended soils. On average, 123 and 114 dominant eubacterial
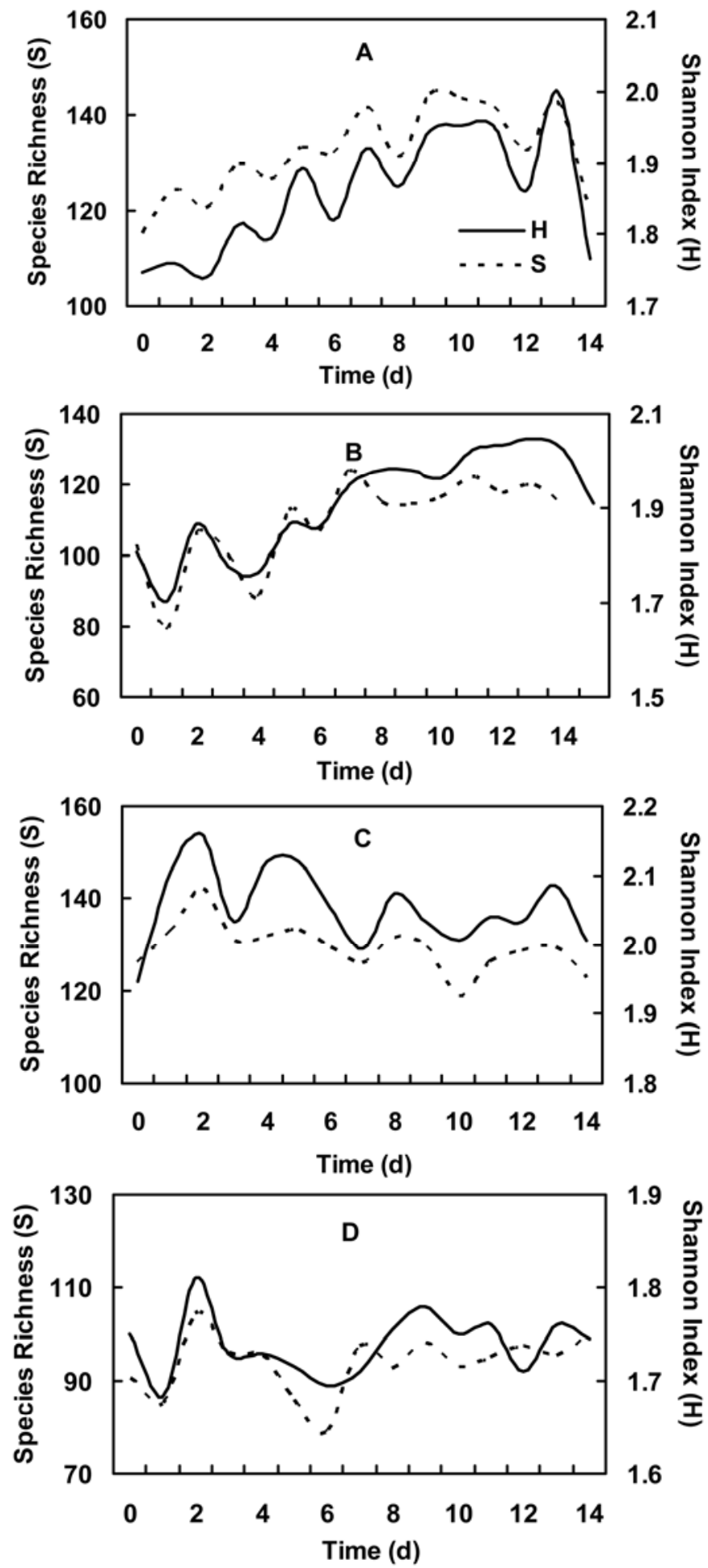

Fig. 4. Species richness $(\mathrm{S})$ and Shannon diversity index $(\mathrm{H})$ of DGGE fragments detected in samples from $\mathbf{A}$, grass-clover-amended organic soil; $\mathbf{B}$, grass-clover-amended conventional soil; $\mathbf{C}$, composted manure-amended organic soil; D, and composted manure-amended conventional soil. amplicons could be distinguished on gels of DNA extracted from GC-amended organic and conventional soils, respectively, and 138 and 98 bacterial fragments in CM-treated organic and conventional soils, respectively, supporting the idea that higher diversity existed in the soils with lower density of bacterial CFU. Both indicators of bacterial diversity in amended soils, species richness and Shannon index, fluctuated over time (Fig. 4). During the first week after GC incorporation, the diversity indices were relatively low, but they climbed again in the second week in an oscillatory fashion. Oscillations in microbial diversity were also seen after CM amendment but without a specific trend during the 2-week observational period. Species richness had significant positive cross-correlations with soil $\mathrm{CO}_{2}$ emission rates in $\mathrm{CM}$ amended organic soil (Table 1). The Shannon index was positively correlated with $\mathrm{CO}_{2}$ emission in the two amended organic soils when $\mathrm{CO}_{2}$ emission rates were shifted backward 1 day. There were only significant negative correlations between bio-
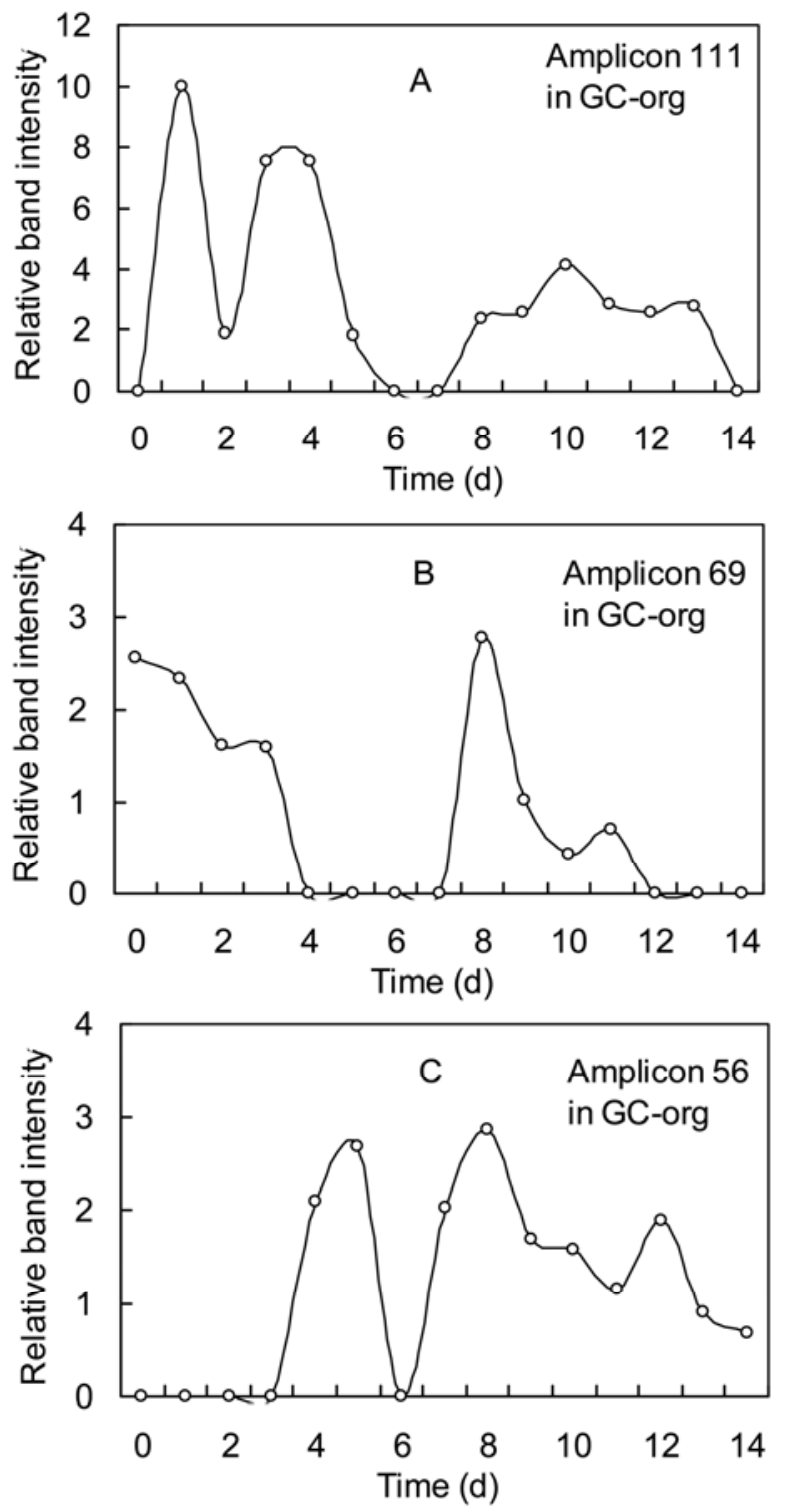

Fig. 5. Relative band intensities of single amplicons of $16 \mathrm{~S}$ rDNA directly extracted from organic soil after incorporation of grass-clover. A, Amplicon at relative band position 111, which went up first and down subsequently, had similar oscillations as copiotrophic $\mathrm{CFU}$, and cross-correlated to area under the disease progress curve (AUDPC); B, amplicon at relative band position 69, which went down first and up subsequently, cross-correlated to AUDPC but was not significantly related to CFU; C, amplicon at relative band position 56, which was absent in the beginning of the experiment and was negatively correlated to AUDPC later. 
diversity measures and copiotrophic CFU in CM-amended conventional soil. However, no significant correlations were found between fluctuations in AUDPC and biodiversity measures.

The intensities of individual bacterial DNA fragments also fluctuated over time after the nutrient inputs (Fig. 5). We divided amplified fragments into bands with high intensities and bands with low intensities. The cut-off points for high-intensity versus low-intensity bands on DGGE gels are shown in Table 2. Amplified fragments with a higher overall intensity often went up first and then declined (Fig. 5A). These fragments always had oscillations similar to those of copiotrophic CFU, and correlated with AUDPC at short lag periods. The intensities of weak bands sometimes declined first, then increased, and fluctuated in tandem with the AUDPC data at lags of several days but were not related to CFU (Fig. 5B). Some weak bands were absent in the beginning and negatively correlated to AUDPC later (Fig. 5C). Cross-correlations analysis demonstrated that the amplicons with significant (mostly positive) correlations to AUDPC formed 38.37 and $29.15 \%$ of all bands in GC-amended organic and conventional soils, respectively (Table 3 ). In the CM-treated organic and conventional soils, the amplified fragments significantly related to AUDPC represented 20.30 and $16.53 \%$ of all bands, respectively, but the correlations were mainly negative (Table 3 ).

\section{DISCUSSION}

We used 16S DNA amplification combined with DGGE to study the daily changes in bacterial communities after a nutrient impulse and relations between fluctuations in measurable bacterial communities and those in pathogen infection during 14 days in two different soils. Harmonics analyses were not carried out for this relatively short period (due to limitations of the number of lanes on a DGGE gel) but significant oscillations were shown previously for longer series (21 days) of AUDPC for Pythium damping-off and CFU over time (18). In the 14-day experiments, AUDPC values were significantly positively cross-correlated to copiotrophic populations when AUDPC were moved backward or forward several days in experiments with GC and CM, respectively. This result was similar to those of the 21-day experiments (18) but values of cross-correlation functions were higher in the 14-day data sets, confirming that the strongest oscillations in AUDPC and CFU took place during the first 2 weeks after nutrient inputs (18).

In this article, we showed that short-term changes of individual bands in DGGE gels with DNA extracted directly from soil showed oscillatory patterns after incorporation of organic ma- terials into soil. This result was similar to the wavelike pattern in individual bacterial DNA fragments from DGGE analysis observed along wheat roots (41). For the first time, we demonstrated that the variations of a large proportion of individual DGGE bands correlated or cross-correlated with the extent of $P$. ultimum infection expressed as AUDPC. High-intensity fragments in the DGGE gels had oscillations similar to the AUDPC values but with short, mostly positive time lags, meaning that changes in the amplicons preceded similar changes in AUDPC. The fluctuations in the high-intensity amplicons were matched by oscillations in copiotrophic CFU. These DGGE fragments may have represented competitive species and antagonists among fast-growing bacteria. Other, less-intense fragments had mostly negative cross-correlations with AUDPC but no significant relations with copiotrophic bacteria. The species with lower population densities (and band intensities) seemed to dominate the microbial communities in organic- and CM-amended soils. Moreover, the DGGE fragments which were absent in the beginning also showed relations with AUDPC, suggesting that organic amendments could increase the activity and biomass of antagonistic bacteria over time or bring new species into the soil. In previous studies, single species of antagonistic bacteria were shown to suppress root pathogen infections $(14,17)$ but reports of relationships between groups of soil microbial communities based on DGGE analysis are relatively rare $(22,30,44)$. Workneh et al. (43), Hiddink et al. (20), and van Bruggen et al. (39) argued that general root disease suppression was not associated with one particular species but with bacterial communities and microbial diversity.

The short-term fluctuations of AUDPC mostly showed positive correlations or cross-correlations with changes of amplicons detected by DGGE in the spring experiment whereas, in CMamended soils, AUDPC was mainly negatively correlated or cross-correlated to relative intensity of individual bands, suggesting that input of different organic materials to soil might represent diverse pathogen-suppressive principles. CM likely had much more native antagonistic bacteria to pathogens $(24,32)$ and steadier nutrient levels than GC. Consequently, CM-amended soils seemed to be more stable, with smaller fluctuations in AUDPC than GC-amended soils. GC had higher concentrations of available carbon and nitrogen (18), which could be utilized by both bacteria and pathogen immediately after addition into soils. Presumably, competition between fast-growing bacteria and the pathogen was the major principle of temporary disease suppression in GC-amended soils, indicated by alternating peaks in copiotrophic CFU and AUDPC (at 2- to 4-day lags) as well as high-intensity individual bands.

TABLE 2. Cut-off points for high-intensity (HI) versus low-intensity (LI) bands on DGGE gels of 16S rDNA directly extracted from grass-clover (GC) or composted manure (CM) amended organic (Org) and conventional (Conv) soil

\begin{tabular}{|c|c|c|c|c|c|c|c|c|}
\hline \multirow[b]{2}{*}{ Parameters } & \multicolumn{2}{|c|}{ Org-GC } & \multicolumn{2}{|c|}{ Conv-GC } & \multicolumn{2}{|c|}{ Org-CM } & \multicolumn{2}{|c|}{ Conv-CM } \\
\hline & HI & LI & HI & LI & HI & LI & HI & LI \\
\hline Range of intensities & $2.48-10.99$ & $0-2.48$ & $2.03-9.39$ & $0-2.03$ & $1.82-6.91$ & $0-1.82$ & $2.49-9.61$ & $0-2.49$ \\
\hline Total intensities (\%) & $51-56$ & $44-49$ & $58-64$ & $36-42$ & $59-64$ & $36-41$ & $59-61$ & 39-41 \\
\hline
\end{tabular}

TABLE 3. Relationships between area under the disease progress curve (AUDPC) and amplicons in DGGE gels of 16S rDNA directly extracted from grass-clover (GC) or composted manure (CM) amended organic (Org) and conventional (Conv) soil ${ }^{\mathrm{a}}$

\begin{tabular}{|c|c|c|c|c|c|c|c|c|c|c|c|c|}
\hline \multirow[b]{2}{*}{ Correlation } & \multicolumn{3}{|c|}{ Org-GC bands (\%) } & \multicolumn{3}{|c|}{ Conv-GC bands (\%) } & \multicolumn{3}{|c|}{ Org-CM bands (\%) } & \multicolumn{3}{|c|}{ Conv-CM bands ( $\%$ ) } \\
\hline & $\mathrm{Lag}=0$ & $\mathrm{Lag}<0$ & Lag $>0$ & $\mathrm{Lag}=0$ & $\mathrm{Lag}<0$ & $\mathrm{Lag}>0$ & $\mathrm{Lag}=0$ & $\mathrm{Lag}<0$ & $\mathrm{Lag}>0$ & $\mathrm{Lag}=0$ & Lag $<0$ & $\mathrm{Lag}>0$ \\
\hline Positive & 5.04 & 13.95 & 16.28 & 2.78 & 6.25 & 10.40 & 0 & 1.49 & 0.99 & 0.9 & 1.42 & 1.42 \\
\hline Negative & 0.78 & 1.16 & 1.16 & 2.08 & 3.47 & 4.17 & 2.97 & 4.95 & 9.90 & 2.84 & 4.74 & 5.21 \\
\hline Total $(\%)^{b}$ & & 38.37 & & & 29.15 & & & 20.30 & & & 16.53 & \\
\hline
\end{tabular}

${ }^{a}$ Lag $<0$ means that variation of AUDPC leads the changes of amplicons; Lag $>0$ means that variation of AUDPC follows the changes of amplicon; the lag unit is 1 day.

b Total numbers of bands were 123, 114, 138, and 98 for Org-GC, Conv-GC, Org-CM, and Conv-CM, respectively. 
Another potential reason for different relations between damping-off intensity and measurable bacterial composition in the two experiments could be oxygen concentration. Although we did not determine $\mathrm{O}_{2}$ content, much higher concentrations of $\mathrm{NH}_{4}{ }^{+}(18)$ and larger peaks of $\mathrm{N}_{2} \mathrm{O}$ (unpublished data) in the GC-amended than CM-amended soil indicated that temporary anaerobic conditions occurred to a greater extent in the GC-amended soils. The microbial community structures were likely different in anaerobic and aerobic microniches, leading to differences in bacterial abilities to compete with $P$. ultimum.

The biodiversity detected by DGGE analysis in both amended soils of two experiments exhibited short-term fluctuations after a disturbance by nutrient incorporation. The oscillations in bacterial diversity dampened with time, especially after CM incorporation, but the diversity remained relatively high. In contrast, oscillations in bacterial diversity continued while the average diversity level increased in GC-amended soils, associated with a gradual decline in AUDPC oscillations. Thus, the effect of GC amendment on bacterial communities and pathogen infection was of shorter duration than that of $\mathrm{CM}$ amendment, which was also observed before $(2,27)$ but not in a time series.

No correlations were found between copiotrophic CFU and biodiversity in soils. This result was different from the results of van Diepeningen et al. (41), who reported that an increase of fastgrowing bacterial populations might cause local loss in biodiversity after a disturbance in soil. These different findings could be attributed to the higher biodiversity in our study $(\approx 70$ to 80 DGGE bands were detected in the study of van Diepeningen and her colleagues whereas $>100$ bands were found in our study). The more biodiversity exists in soil, the less fast-responding species influence soil community structure (39).

Microbial activity, assessed as $\mathrm{CO}_{2}$ respiration, increased significantly in organic and conventional soils after nutrient impulses from fresh plant material or $\mathrm{CM}$. Fluctuations in $\mathrm{CO}_{2}$ emission rates occurred within the first 7 days and were less pronounced than those in copiotrophic CFU. Chen et al. (7) also found that microbial activity, measured by the rate of hydrolysis of fluorescein diacetate, fluctuated during a 7-day experiment after amending container media with composted hardwood bark. Significant correlations between microbial activity and disease severity were observed (7). In the research reported here, however, $\mathrm{CO}_{2}$ respiration from total soil microorganisms did not seem to influence the fluctuations in $P$. ultimum infection after nutrient impulses in 14-day experiments. The background levels of available nutrients might be the reason for the different results.

In conclusion, soil measurable bacterial communities and microbial activities fluctuated after nutrient input into two different soils. The oscillations in damping-off intensities by $P$. ultimum could be explained by increases and decreases of groups of microbial species in amended soils but could not be directly related to variations of bacterial activities. Although it is difficult to detect specific bacteria for plant disease control among hundreds of species in soil, our observations lead to an approach to identify antagonists or competitors of plant pathogens by searching at particular moments in time relative to a disturbance, cutting selected DNA fragments from the DGGE gels, and sequencing these fragments. Finally, the higher biodiversity and much steadier fluctuations in microbial community composition after a disturbance by CM than by GC indicated a greater stability in CM-amended soils.

\section{ACKNOWLEDGMENTS}

This work was partially supported by grant number 047.017 .011 of the Dutch-Russia Scientific Cooperation Program of NWO, The Netherlands entitled "Resilience of microbial communities to disturbances as an indicator of sequestration of $\mathrm{C}$ and $\mathrm{N}$ in soil: comparison of agricultural and semi-natural ecosystems". Additional support was obtained from the
Asia-Link Project "Organic farming: ethical, economic, technical and scientific aspects in a global perspective" CN/ASIA-LINK/028 (108962), National Natural Science Foundation of China (51008107, 40871101, and 40901142), and Natural Science Foundation of Zhejiang province (Y5100030). We thank A. Siepel for his help with selection and sampling of the soils; W. Ma, A. Khodzaeva, and D. Volker for helping us with the experiments; and O. de Vos for help with the DGGE analyses.

\section{LITERATURE CITED}

1. Arias, M. E., Gonzalez-Perez, J. A., Gonzalez-Vila, F. J., and Ball, A. S. 2005. Soil health-a new challenge for microbiologists and chemists. Int. Microbiol. 8:13-21.

2. Bulluck, L. R., III, and Ristaino, J. B. 2002. Effect of synthetic and organic soil fertility amendments on southern blight, soil microbial communities, and yield of processing tomatoes. Phytopathology 92:181-189.

3. Cairns, M. J., and Murray, V. 1994. Rapid silver staining and recovery of PCR products separated on polyacrylamide gels. BioTechniques 17:915919.

4. Calderón, F. J., Jackson, L. E., Scow, K. M., and Rolston, D. E. 2001. Short-term dynamics of nitrogen, microbial activity, and phospholipid fatty acids after tillage. Soil Sci. Soc. Am. J. 65:118-126.

5. Campbell, C. L., and Madden, L. V. 1990. Page 532 in: Introduction to Plant Disease Epidemiology. Wiley-Interscience, New York.

6. Chen, W., Hoitink, H. A. J., and Madden, L. V. 1988. Microbial activity and biomass in container media for predicting suppressiveness to damping-off caused by Pythium ultimum. Phytopathology 78:1447-1450.

7. Chen, W. D., Hoitink, H. A. J., Schmitthenner, A. F., and Tuovinen, O. H. 1988. The role of microbial activity in suppression of damping-off caused by Pythium ultimum. Phytopathology 78:314-322.

8. Culman, S. W., Duxbury, J. M., Lauren, J. G., and Thies, J. E. 2006. Microbial community response to soil solarization in Nepal's rice-wheat cropping system. Soil Biol. Biochem. 38:3359-3371.

9. Darby, H. M., Stone, A. G., and Dick, R. P. 2006. Compost and manure mediated impacts on soilborne pathogens and soil quality. Soil Sci. Soc. Am. J. 70:347-358.

10. de Vos, O. J., and van Bruggen, A. H. C. 2001. Soil microbial composition as affected by grass-clover mixture incorporation in the soil. ISME 9:17.077.

11. Eichner, C. A., Erb, R. W., Timmis, K. N., and Wagner-Dőbler, I. 1999. Thermal gradient gel electrophoresis analysis of bioprotection from pollutant shocks in the activated sludge microbial community. Appl. Environ. Microbiol. 65:102-109.

12. Ellis, R. J., Timms-Wilson, T. M., Beringer, J. E., Rhodes, D., Renwick, A., Stevenson, L., and Bailey, M. J. 1999. Ecological basis for biocontrol of damping-off disease by Pseudomonas fluorescens 54/96. J. Appl. Microbiol. 87:454-463.

13. Garbeva, P., van Veen, J. A., and van Elsas, J. D. 2004. Assessment of the diversity, and antagonism towards Rhizoctonia solani AG3, of Pseudomonas species in soil from different agricultural regimes. FEMS Microbiol. Ecol. 47:51-64.

14. Georgakopoulos, D. G., Fiddaman, P., Leifert, C., and Malathrakis, N. E. 2002. Biological control of cucumber and sugar beet damping-off caused by Pythium ultimum with bacterial and fungal antagonists. J. Appl. Microbiol. 92:1078-1086.

15. Giuliano, B., Vincenzo, A., Manuela, C, and Felice, S. 2010. Identifying the characteristics of organic soil amendments that suppress soilborne plant diseases. Soil Biol. Biochem. 42:136-144.

16. Gorissen, A., van Overbeek, L. S., and van Elsas, J. D. 2004. Pig slurry reduces the survival of Ralstonia solanacearum biovar 2 in soil. Can. J. Microbiol. 50:587-593.

17. Grosch, R., Scherwinski, K., Lottmann, J., and Berg, G. 2006. Fungal antagonists of the plant pathogen Rhizoctonia solani: Selection, control efficacy and influence on the indigenous microbial community. Mycol. Res. 110:1464-1474.

18. He, M. M., Ma, W. J., Tian, G. M., Blok, W., Khodzaeva, A., Zelenev, V. V., Semenov, A. M., and van Bruggen, A. H. C. 2010. Daily changes of infections by Pythium ultimum after a nutrient impulse in organic versus conventional soils. Phytopathology 100:593-600.

19. Heuer, H., and Smalla, K. 1997. Application of denaturing gradient gel electrophoresis for studying soil microbial communities. Pages 353-373 in: Modern Soil Microbiology. J. D. van Elzas, J. T. Trevors, and E. M. H. Wellington, eds. Marcel Dekker Inc., New York.

20. Hiddink, G. A., van Bruggen, A. H. C., Termorshuizen, A. J., Raaijmakers J. M., and Semenov, A. V. 2005. Effect of organic management of soils on suppressiveness to Gaeumannomyces graminis var. tritici and its antagonist, Pseudomonas fluorescens. Eur. J. Plant Pathol. 113:417-435.

21. Hjort, K., Lembke, A., Speksnijder, A., Smalla, K., and Jansson, J. K. 2007. Community structure of actively growing bacterial populations in 
plant pathogen suppressive soil. Microbiol. Ecol. 53:399-413.

22. Hunter, P. J., Petch, G. M., Calvo-Bado, L. A., Pettitt, T. R., Parsons, N. R., Morgan, J. A., and Whipps, J. M. 2006. Differences in microbial activity and microbial populations of peat associated with suppression of damping-off disease caused by Pythium sylvaticum. Appl. Environ. Microbiol. 72:6452-6460.

23. Joshi, D., Hooda, K. S., Bhatt, J. C., Mina, B. L., and Gupta, H. S. 2009. Suppressive effects of composts on soil-borne and foliar diseases of French bean in the field in the western Indian Himalayas. Crop Prot. 28:608-615.

24. Kavroulakis, N., Ntougias, S., Besi, M. I., Katsou, P., Damaskinou, A., Ehaliotis, C., Zervakis, G. I., and Papadopoulou, K. K. 2010. Antagonistic bacteria of composted agro-industrial residues exhibit antibiosis against soil-borne fungal plant pathogens and protection of tomato plants from Fusarium oxysporum f. sp. radicis-lycopersici. Plant Soil 333:233-247.

25. Kozdrój, J., and van Elsas, J. D. 2000. Response of the bacterial community to root exudates in soil polluted with heavy metals assessed by molecular and cultural approaches. Soil Biol. Biochem. 32:1405-1417.

26. Larkin, R. P., Griffin, T. S., and Honeycutt, C. W. 2010. Rotation and cover crop effects on soilborne potato diseases, tuber yield, and soil microbial communities. Plant Dis. 94:1491-1502.

27. Liu, B., Gumpertz, M. L., Hu, S. J., and Ristaino, J. B. 2007. Long-term effects of organic and synthetic soil fertility amendments on soil microbial communities and the development of southern blight. Soil Biol. Biochem. 39:2302-2316

28. Muyzer, G., De Waal, E. C., and Uitterlinden, A. G., 1993. Profiling of complex microbial populations by denaturing gradient gel electrophoresis analysis of polymerase chain reaction-amplified genes for 16S rRNA. Appl. Environ. Microbiol. 59:695-700.

29. Pérez-Piqueres, A., Edel-Hermann, V., Alabouvette, C., and Steinberg, C. 2006. Response of soil microbial communities to compost amendments. Soil Biol. Biochem. 38:460-470.

30. Postma, J., Geraats, B. P. J., Pastoor, R., and van Elsas, J. D. 2005. Characterization of the microbial community involved in the suppression of Pythium aphanidermatum in cucumber grown on rockwool. Phytopathology 95:808-818.

31. Postma, J., Schilder, M. T., Bloem, J., and van Leeuwen-Haagsma, W. K. 2008. Soil suppressiveness and functional diversity of the soil microflora in organic farming systems. Soil Biol. Biochem. 40:2394-2406.

32. Pugliese, M., Liu, B. P., Gullino, M. L., and Garibaldi, A. 2008. Selection of antagonists from compost to control soil-borne pathogens. J. Plant Dis. Prot. 115:220-228.

33. Rosado, A. S., Duarte, G. R., Seldin, L., and van Elsas, J. D. 1998. Genetic diversity of nifH gene sequences in Paenibacillus azotofixans strains and soil samples analyzed by denaturing gradient gel electrophoresis of PCR-amplified gene fragments. Appl. Environ. Microbiol. 64:2770-2779.
34. Santos, I., and Bettiol, W. 2003. Effect of sewage sludge on the rot and seedling damping-off of bean plants caused by Sclerotium rolfsii. Crop Prot. 22:1093-1097.

35. Semenov, A. M., van Bruggen, A. H. C., and Zelenev, V. V. 1999. Moving waves of bacterial populations and total carbon along roots of wheat. Microbiol. Ecol. 37:116-128.

36. Thuerig, B., Fliessbach, A., Berger, N., Fuchs, J. G., Kraus, N., Mahlberg, N., Nietlispach, B., and Tamm, L. 2009. Re-establishment of suppressiveness to soil- and air-borne diseases by re-inoculation of soil microbial communities. Soil Biol. Biochem. 41:2153-2161.

37. Tiquia, S. M., Lloyd, J., Herms, D. A., Hoitink, H. A. J., and Michel, F. C. 2002. Effects of mulching and fertilization on soil nutrients, microbial activity and rhizosphere bacterial community structure determined by analysis of TRFLPs of PCR-amplified 16S rRNA genes. Appl. Soil Ecol. 21:31-48.

38. van Bruggen, A. H. C., and Semenov, A. M. 1999. A new approach to the search for indicators of root disease suppression. Australas. Plant Pathol. 28:4-10.

39. van Bruggen, A. H. C., Semenov, A. M., van Diepeningen, A. D., de Vos, O. J., and Blok, W. J. 2006. Relation between soil health, wave-like fluctuations in microbial populations, and soil-borne plant disease management. Eur. J. Plant Pathol. 115:105-122.

40. van Bruggen, A. H. C., Semenov, A. M., and Zelenev, V. V. 2002. Wavelike distributions of infections by an introduced and naturally occurring root pathogen along wheat roots. Microbiol. Ecol. 44:30-38.

41. van Diepeningen, A. D., de Vos, O. J., Zelenev, V. V., Semenov, A. M., and van Bruggen, A. H. C. 2005. DGGE fragments oscillate with or counter to fluctuations in cultivable bacteria along wheat roots. Microbiol. Ecol. 50:506-517.

42. Veeken, A. H. M., Blok, W. J., Curcia, F., Coenen, G. C. M., Termorshuizen, A. J., and Hamelers, H. V. M. 2005. Improving quality of composted biowaste to enhance disease suppressiveness of compostamended, peat-based potting mixes. Soil Biol. Biochem. 37:2131-2140.

43. Workneh, F., and van Bruggen, A. H. C. 1994. Microbial density, composition, and diversity in organically and conventionally managed rhizosphere soil in relation to suppression of corky root of tomatoes. Appl. Soil Ecol. 1:219-230.

44. Yang, C. H., Crowley, D. E., and Menge, J. A. 2001. 16S rDNA fingerprinting of rhizosphere bacterial communities associated with healthy and Phytophthora infected avocado roots. FEMS Microbiol. Ecol. 35:129-136.

45. Yin, C. T., Jones, K. L., Peterson, D. E., Garrett, K. A., Hulbert, S. H., Paulitz, T. C., and Timothy, C. 2010. Members of soil bacterial communities sensitive to tillage and crop rotation. Soil Biol. Biochem. 42:2111-2118.

46. Zelenev, V. V., van Bruggen, A. H. C., and Semenov, A. M. 2005. Shortterm wavelike dynamics of bacterial populations in response to nutrient input from fresh plant residues. Microbiol. Ecol. 49:83-93. 